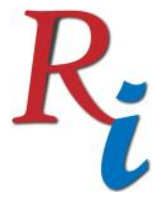

Asia Proceedings of Social Sciences

(APSS)

www.readersinsight.net/APSS

\title{
ENERGY EFFICIENCY SAVING FINANCING IN INDONESIA: LCC ANALYSIS
}

\section{Eka Sudarmaji *}

Fakultas Ekonomi and Bisnis

University of Pancasila, Jalan Srengseng Sawah, Pasar Minggu Jakarta

Indonesia

esudarmaji@univpancasila.ac.id

\section{Yuli Ardianto}

Fakultas Ekonomi and Bisnis

University of Pancasila, Jalan Srengseng Sawah, Pasar Minggu Jakarta

Indonesia

*Corrosponding author's Email: esudarmaji@ univpancasila.ac.id

Peer-review under responsibility of $5 t^{d}$ Asia International Conference 2019 Scientific Committee http://connectingasia.org/scientific-committee/

(C) 2019 Published by Readers Insight Publisher, lat 306 Savoy Residencia, Block 3 F11/1,44000 Islamabad. Pakistan,

editor@readersinsight.net

This is an open-access article under the CC BY-NC-ND license (http://creativecommons.org/licenses/by-nc-nd/4.0/). 


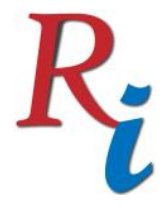

Asia Proceedings of Social Sciences

(APSS)

www.readersinsight.net/APSS

\section{A b s t r a c t}

This paper to set up an initial model in developing the model for Energy Saving Companies in Indonesia in assessing alternative financing for Energy Efficiency Saving in Indonesia. The reviewed for all the energy efficiency saving advantages cover the upfront investment costs are presented. The model is using the Analytic Hierarchy Process (AHP) and life cycle cost (LCC) analysis, with sensitivity analysis, is presented under possible a game-theory process. On some occasions, these alternative financing values are comparing to other similar investment returns as well as the risks.

Keyword: LCCA, AHP, Alternatif Financing, Energy Efficiency Saving

\section{Rese a r ch High I ight s}

Life cycle cost (LCC) is one sort of a procedure for assessing the total cost of ownership between totally unrelated other options. LCC can be utilized as a monetary strategy for assessing investment costs of all costs of owning, operating, and abandoning the benefit (Fuller \& Petersen, 1996). It is the sunk cost of procuring, utilizing and holding an asset for a period of time (Mearig, Coffee, \& Morgan, 1999). In other word, LCC is a significant apparatus for positioning the expense of proprietorship between totally unrelated other options. Prior assumption can be made upon the performance of comparative resources, surveys, having the data from producers, sellers, temporary workers, and using standard maintenance costs (Robinson, 1996). Under the LCC technique, we present the evaluations of the "investment cost" on energy saving compared to other project investments. The benefit of energy efficiency's saving as they are collecting overtime-associated with electricity generation expenditures. The summarized for all the energy efficiency saving benefits cover the upfront investment costs are presented.

\section{Research Objectives}

This investigation proposes a basic decision-making structure that: (1) ascertains the monetary advantages of retrofit financing as far as life-cycle cost for a specific energy efficiency's lamp during its service life; (2) decides the ideal retrofitting spending that minimizes the total life- 


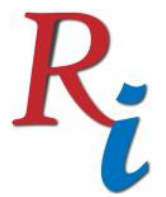

\section{Asia Proceedings of Social Sciences (APSS) \\ www.readersinsight.net/APSS}

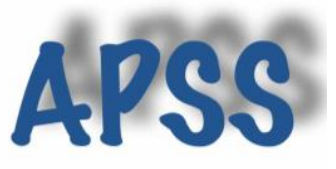

cycle cost of the energy efficiency's lamp during its service-life; and (3) chooses the ideal retrofitting technique (using sensitivity analysis) to amplify the retrofit supplier financial advantages during service-life of the energy efficiency lamp based on available investments.

\section{Methodology}

This research is a case study, semi-structured deep interviews organized with owners and directors who managed retrofit projects. The interview process helps the information obtained, which can only be obtained directly from persons involved. Optional information acquired from industry information and retrofit project archive information is utilized to understand the lighting and energy-saving industry. This initial step enables the authors to have the option to recognize the key components of the survey given, Interviews are directed between January to June 2019, enduring from twenty minutes to an hour. Every respondent was approached to remark on the accompanying points: 1) their meaning of energy-saving or energy efficiency; 2) the idea of energy efficiency (EE) innovation and vitality sparing gear: its starting point; 3) the execution strategies, and how it detects the retrofit methodology; 4) key variables for the accomplishment of the retrofit procedure; 5) the role of energy efficiency in a manageable retrofit procedure.

\section{Results}

The outcomes of the whole process, based on the interviews and questionnaires, and based on the results of tests conducted on the AHP method with Super Decision software. The Price Energy Price 'criteria were found to determine 3 criteria or factors determining the uncertainty in the LCC analysis in the retrofitting program. The factors determining the uncertainty in the determination or calculation of LCC analysis to decide alternative sources of loans for determining energy efficiency savings targets through a retrofitting program are found in table 4 below. The six determinants of life cycle cost calculation are 1) LCCA 1: Energy Consumption, 2) LCCA 2: Energy Price, 3) LCCA 3: Equity Service Life, 4) LCCA 4: Installation \& Replacement Cost, 5) LCCA 5: Operation, Repair \& Maintenance and 6) LCCA 6: Residual Value. 


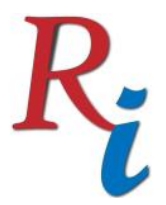

Asia Proceedings of Social Sciences

(APSS)

www.readersinsight.net/APSS

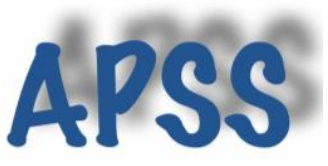

Table.1: Overall result on factors determining the uncertainty

\begin{tabular}{lccc}
\hline \multicolumn{1}{c}{ Name } & Ideals & Normal & Raw \\
\hline Energy Consumption & 0.6740 & 0.2179 & 0.1089 \\
Energy Price & 1.0000 & 0.3232 & 0.1616 \\
Equip Service Life & 0.2460 & 0.0795 & 0.0398 \\
Installation \& Replacement & 0.4378 & 0.1415 & 0.0708 \\
OPR, Repair \& Maintenance & 0.5170 & 0.1671 & 0.0836 \\
Residual Value & 0.2189 & 0.0708 & 0.0354
\end{tabular}

\section{Findings}

Cluster research results: Retrofitting, placing ESPC with a suspension of 0.6734 in the top position compared with ESA and Traditional Loans with a suspension of 0.2515 and 0.0751 . Based on the ESA cluster, placing 'Energy Price' with a suspension of 0.3906 in the top position compared to Energy Consumption, Equipment Service Life with a suspension, Installation \& Replacement Cost, Operation, Repair \& Maintenance and Residual Value with a suspension respectively $0.1928,0.1257,0.0921,0.1829$ and 0.0160 . On the other hand, based on the ESPC cluster, placing 'Energy Price' by 0.2869 in the top position compared to Energy Consumption, Equipment Service Life, Installation \& Replacement Cost, Operation, Repair \& Maintenance and Residual Value with a suspension of $0.2415,0.0649,0.1616,0.1494$ and 0.00956 . For the results of the Traditional Loans cluster, place 'Energy Price' with the amount of 0.4236 in the top position compared to Energy Consumption, Equipment Service Life, Installation \& Replacement Cost, Operation, Repair \& Maintenance and Residual Value with a suspension of $0.0898,0.0553,0.1271,0.2729$ and 0.0313 .

In response to intense competition, company ' $\mathrm{X}$ ' changed its marketing strategy, by breaking the barriers between product-dominant and service-dominant strategy, the business model of a Product Service System (PSS) considered as a strategic approach that enables the company from selling mere products to deliver a unique and positive experiences to users while traveling with a solution that is customized and results-oriented. Discount or cost-cutting programs are transformed into customer-centered value through the implementation of PSS business models, which aim to increase product and service variability. After the conclusion, it is believed that further investigation into several other contexts needs to be explored. Based on these findings, 


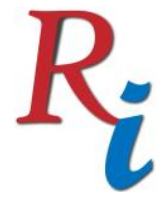

\section{Asia Proceedings of Social Sciences}

(APSS)

www.readersinsight.net/APSS

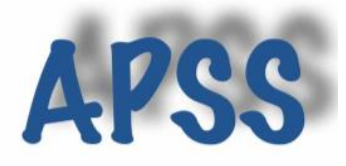

future research needs to be carried out to examine interactions between various problems, such as the environment, industry, or economy and apply various theories to enhance an in-depth understanding of LED market opportunities and energy efficiency. In concluding this paper, there is always room for improvement to be made.

\section{References}

Fuller, S. K., \& Petersen, S. R. (1996). LCCosting Manual for the Federal Energy Management Program. NIST Handbook 135.

Mearig, T., Coffee, N., \& Morgan, M. (1999). Life Cycle Cost Analysis Handbook.

Nasip, I., \& Sudarmaji, E. (2018a). Government Measures to Promote New Retrofitting Business and Financing Option in Indonesia. International Journal of Engineering and Technology (IJET), 7(3.25), 531-537.

Nasip, I., \& Sudarmaji, E. (2018b). Managing Tax Dispute Due to IFRS-16 on the Retrofits Implementation in Indonesia. International Journal of Engineering and Technology (IJET), 7(3.21), 200-208.

Saaty, T. L. (2008). Decision Making with The Analytic Hierarchy Process. International Journal Services Sciences, 1(1), 83-98.

Taha, R. A., \& Daim, T. (2013). Multi-Criteria Applications in Renewable Energy Analysis, a Literature Review. Green Energy and Technology, 60, 17-30.

Author's Biography

Eka Sudarmaji is a Doctoral student in Finance at IPB University, Bogor, Indonesia. He is currently a Researcher and Lecturer at the University of Pancasila, Jakarta, Indonesia. His research interests are business innovation, energy efficiency, entrepreneurship, capital market, and strategic management. 


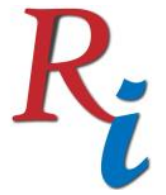

\section{Asia Proceedings of Social Sciences}

(APSS)

www.readersinsight.net/APSS

Yuli Ardianto is a Doctoral student in Strategic Management at Pancasila University, Indonesia. He is currently a Researcher and Lecturer at the University of Pancasila, Jakarta, Indonesia. His research interests are Tax and International Tax, entrepreneurship, Marketing Strategic 